\title{
A SELETIVIDADE ESPACIAL DA PICHAÇÃO EM BELO HORIZONTE: ENTRE A NOTORIEDADE E A EFEMERIDADE
}

\author{
Rodrigo Guedes Braz Ferreira \\ Pontifícia Universidade Católica de Minas Gerais - PUC Minas, Brasil \\ rodriguedes13@hotmail.com \\ Alexandre Magno Alves Diniz \\ Pontifícia Universidade Católica de Minas Gerais - PUC Minas, Brasil \\ alexandremadiniz@gmail.com
}

\begin{abstract}
RESUMO
A pichação é uma manifestação gráfica, predominantemente desenvolvida por meio da escrita ou de desenhos mesclados com escritas, muitas vezes de difícil interpretação, que se encontra amplamente presente nas cidades brasileiras. Este artigo busca identificar como os pichadores percebem e valorizam os aspectos presentes na paisagem urbana, selecionando os locais a serem pichados. Com base em levantamento primário de informações, um grupo de pichadores foi convidado a identificar em plantas e mapas locais "desejados" e a serem "evitados" na sua atuação. O Hipercentro de Belo Horizonte foi usado como referência, tendo sido adotado um conjunto de instrumentos para a coleta de informações: a) planta cartográfica; b) plantas de fachadas de prédios e casas; c) roteiro de entrevistas. Os resultados revelam que os pichadores possuem uma lógica espacial que privilegia e/ou evita locais segundo as atividades e funções urbanas ali presentes; a presença e a circulação de pessoas; e a visibilidade dos locais. Concluiu-se que os pichadores, enquanto agentes produtores do espaço urbano, experienciam e fazem escolhas espaciais na cidade segundo uma visão e objetivos comuns. Desvelou-se, ainda, vários aspectos relativos ao código de comportamento espacial dos pichadores.
\end{abstract}

Palavras-chave: Pichação. Percepção geográfica. Planta cartográfica. Hipercentro. Comportamento espacial.

\section{THE SPATIAL SELECTIVITY OF GRAFFITI IN BELO HORIZONTE: BETWEEN THE NOTORIETY AND THE EPHEMERALITY}

\begin{abstract}
Graffiti is a graphic manifestation, predominantly developed through writings or drawings mixed with writings, often difficult to interpret, which is widely present across Brazilian cities. This article seeks to identify how the graffiti artists perceive and value the aspects present in the urban landscape, selecting the places to apply graffiti. Based on primary data, a group of taggers was invited to identify on cartographic plans and maps "desired" spots and places to be "avoided" while tagging. The Belo Horizonte Hypercenter was used as a reference, and the following set of instruments was used for collecting information: a) cartographic plan; b) facade plans for buildings and houses; c) script of interviews. The results reveal that the taggers have a spatial logic that privileges and / or avoids places according to the urban activities and functions; the presence and movement of people; and the visibility of locations. It was concluded that the taggers, as agents who produce urban space, experience and make spatial choices in the city according to a common vision and objectives. Several aspects related to the spatial behavioral code of the graffiti artists were also unveiled.
\end{abstract}

Keywords: Graffiti; Geographic perception; Cartographic plan; Hypercenter; Spatial behavior.

\section{INTRODUÇÃO}

A pichação ${ }^{1}$ (Figura 1) é uma ação provocadora, considerada marginal, que flerta com a arte e que parece causar excitação em quem a produz e assombro em quem a recebe, questionando elementos caros à

\footnotetext{
${ }^{1}$ A grafia pixação com "x", no lugar de pichação com "ch", é também encontrada na literatura, referindo-se a uma categoria vernacular adotada por seus praticantes, segundo a qual o ato de "pixar" transcende o simples a ação de escrever em muros e fachadas, representando, também, um estilo de vida específico (PEREIRA, 2005: p. 9).

$\begin{array}{llllll}\text { Caminhos de Geografia } & \text { Uberlândia } & \text { v. 22, n. 84 } & \text { dez/2021 } & \text { p. 119-135 } & \text { Página } 119\end{array}$
}


sociedade como, por exemplo, os limites entre público e privado, ao mesmo tempo em que revela especificidades no modo de vida de indivíduos e de grupos que exploram espaços da cidade para deixar sua própria marca.

Isnardis (1997) define as pichações como "assinaturas, das quais seus autores grafam seus apelidos [...]" e "[..] em geral as assinaturas vêm acompanhadas de pequenas siglas, que correspondem aos nomes dos grupos que congregam os pichadores" (ISNARDIS, 1997 p.146). Por sua vez, Pereira (2010) encara a pichação como "[...] grafia estilizada de palavras nos espaços públicos da cidade que se referem, quase sempre, à denominação de um grupo de jovens ou ao apelido de um pichador individual" (PEREIRA, 2010 p. 146). As pichações "são inscrições monocromáticas, feitas com spray ou rolo de pintura em meio à arquitetura da metrópole" (CARVALHO, 2013 p. 75).

Figura 1 - Belo Horizonte (MG): Pichações em edificação, Hipercentro, 2018

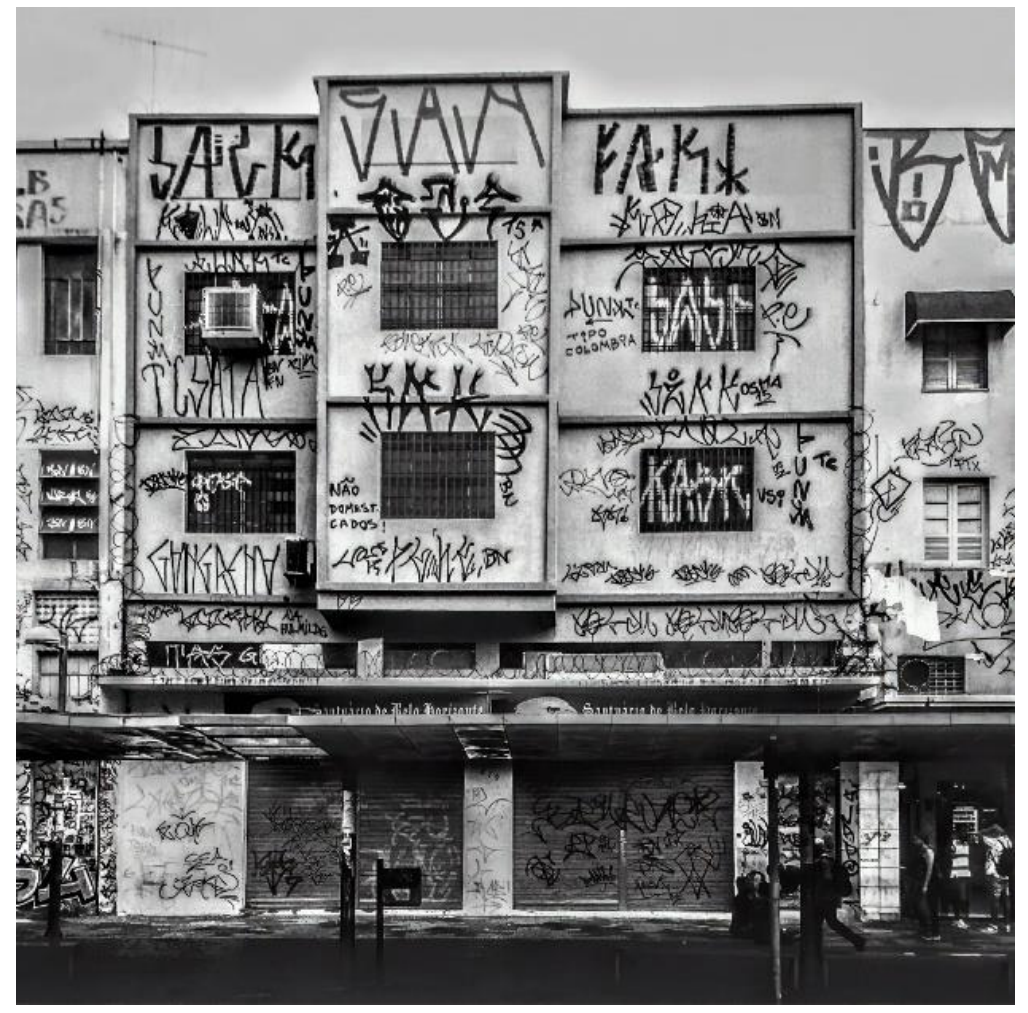

Fonte: Acervo do autor (2018)

O fenômeno da pichação tem despertado o interesse de pesquisadores de diversas áreas com destaque para os trabalhos de Isnardis (1997), Lodi (2003), Pereira (2010), Caldeira (2012), Soares (2013), Carvalho (2013), Soares (2016) e, Silva (2016), não apenas pela ubiquidade do fenômeno nas paisagens urbanas brasileiras, mas também por seu intrínseco apelo multidisciplinar. Entre os geógrafos o tema tem sido recorrente, com destaque para as pesquisas de Mondardo e Goettert (2008), Moren (2009), Tartaglia (2010), Moura (2014), Santos (2015), sendo ainda mais restritos aqueles que retratam a metrópole de Belo Horizonte, com destaque para os estudos de Diniz et al (2015), Diniz et al (2017) e, Diniz et al (2019), com foco na identificação de padrões de distribuição espacial em distintos contextos. Sabe-se que a pichação não se distribui de modo aleatório no espaço, havendo forte seletividade da parte dos pichadores. Por meio da observação da paisagem da cidade, percebe-se geralmente que as pichações são encaixadas cuidadosamente, muitas vezes, sem sobreposição em relação às pichações precedentes, sendo alocadas em suportes diversos, como marquises, muros, topos de edificações, portas de lojas, entre outras construções e equipamentos.

No entanto, sabe-se pouco sobre as motivações e os critérios levados em consideração pelos pichadores na escolha dos locais a serem ou não pichados. Utilizando o Hipercentro de Belo Horizonte como referência, o presente artigo tem como objetivo identificar como os pichadores atuam no espaço; como percebem e valorizam os elementos presentes na paisagem urbana; e quais elementos são levados em consideração na escolha dos locais a serem pichados e aqueles a serem evitados.

\begin{tabular}{llllll}
\hline Caminhos de Geografia & Uberlândia - MG & v. 22, n. 84 & dez/2021 & p. 119-135 & Página 120
\end{tabular}


A pesquisa associa uma abordagem teórico-metodológica da fenomenologia, combinada com análise espacial, buscando explorar a percepção espacial dos pichadores por meio da rotulação de uma planta cartográfica e de um conjunto de imagens de fachadas de casas e prédios e entrevistas em profundidade com a intenção de identificar os processos de seleção espacial e os significados atribuídos a distintos elementos das paisagens.

\section{A FENOMENOLOGIA COMO APORTE TEÓRICO DE PESQUISA}

Para se compreender o processo de incorporação da fenomenologia à Geografia faz-se necessário remeter a origem do pensamento moderno fenomenológico surgido no início do século XX como crítica ao modo positivista de se fazer ciência. Embora Husserl, um dos precursores da fenomenologia, reconhecesse os benefícios e avanços do positivismo científico, desenvolvido desde o século XVI com a revolução científica iniciada por Galileu, ele também reconheceu que daquele momento em diante a ciência passou a guiar-se por uma abordagem físico-matemática da vida, cuja representação era tomada como realidade concreta. Segundo Husserl (1931/2001), o pensamento cartesiano não alcançava a riqueza relacionada à nossa experiência no e do mundo, problema que o fez rejeitar quase todo o conteúdo doutrinário cartesiano.

Como alternativa, Husserl desenvolve uma filosofia na qual a constituição do conhecimento aconteceria por meio da tomada de consciência sobre o fenômeno, segundo a intenção do sujeito e conseguinte à realização da "suspensão fenomenológica". Esta, por sua vez, era entendida como a suspensão de qualquer julgamento, o abandono dos pressupostos em relação ao fenômeno, o que desencadearia um procedimento embasado no exame de conteúdos da consciência do sujeito como caminho para criar e organizar conhecimentos (HOLZER, 2016).

A fenomenologia desenvolvida por Husserl centra esforços na investigação, com rigor, da experiência das pessoas por meio da ciência da experiência e da reflexão. Ele acreditava que por meio da fenomenologia seria possível observar e descrever as coisas como elas se manifestavam e seriam de fato, o encontro com as "coisas mesmas", o fenômeno captado no seu sentido absoluto, diferentemente do tipo de conhecimento resultante da matematização da realidade (MARANDOLA JUNIOR, 2005).

Nesse sentido, para Husserl o estudo do fenômeno se dá a partir da evidência, ou seja, das experiências das "coisas" e dos "fatos" em questão, que nos são apresentados "em si", em suas essências. O conhecimento é fundamentado na captação do sentido absoluto das coisas por meio de evidências que em si revelam os problemas (HUSSERL, 2001, p. 29).

Segundo AMORIM FILHO (2000, p. 75), a fenomenologia é a ciência das essências ou dos significados compreendidos por meio da experiência. Nesse sentido, uma das contribuições importantes de Husserl e também muito usada por geógrafos é a apreensão do conhecimento a partir da noção de "Lebenswelt" - a ideia de "mundo vivido", que permitiria criar uma postura investigativa que adentra o fluxo da vivência das pessoas em seu cotidiano, no tempo e na sociedade.

Como meio de aproximar o modo de fazer pesquisa geográfica ao conhecimento advindo da experiência de indivíduos ou grupos, os geógrafos humanistas transpuseram o conceito de "mundo vivido", até então muito estudado pelos fenomenólogos em sua dimensão filosófica, para a Geografia. Segundo Buttimer (1982), a noção geográfica de mundo vivido sugere essencialmente "as dimensões pré-reflexivas e tomadas como certas, das experiências, os significados não questionados e determinantes do comportamento" (BUTTIMER, 1976 [1982], p. 172).

Entrikin aponta que por meio da fenomenologia o estudo da experiência se tornaria viável e esclarece que: "[...] no lugar de tentar uma explicação filosófica, os fenomenólogos buscam conhecimento por meio da descrição da experiência...[..]" e, parafraseando Edie (1962), Entrikin explica que: "[..] a fenomenologia, no lugar do empirismo, é a ciência da experiência. [...] (ENTRIKIN apud EDIE, 1976, p. 618). Em seguida, Entrikin afirma que: "[...] a fenomenologia é um método [...]" (ENTRIKIN, 1976, p. 619). Assim, por meio do conceito de "mundo-vivido", a fenomenologia e a Geografia, embora estejam em planos diferentes, convergem no estudo da constituição do mundo, por meio da experiência dos indivíduos em seu cotidiano.

Com a fenomenologia e o desenvolvimento da noção de "Lebenswelt", ou, mundo vivido, abriu-se uma nova dimensão para os estudos geográficos. A experiência como meio de conhecimento tornou-se fonte legítima de um tipo de ciência centrada no cotidiano das pessoas. Nesse sentido, os fundamentos da fenomenologia adquirem importância nas análises geográficas, sobretudo, como aporte metodológico e tornam-se essenciais para a Geografia Humanista (AMORIM FILHO, 2000).

$\begin{array}{llllll}\text { Caminhos de Geografia } & \text { Uberlândia - MG } & \text { v. 22, n. } 84 & \text { dez/2021 } & \text { p. 119-135 } & \text { Página } 121\end{array}$


Segundo Oliveira (2009), é no mundo-vivido que se dão as interações entre as pessoas e o espaço, um processo contínuo de troca entre o mundo exterior e o mundo pessoal interior, que resulta na construção da percepção sobre a realidade. Assim, Oliveira (1989) explica que: "[...] os mundos interior e exterior estão sempre interligados no funcionamento do organismo humano; eles interagem e evoluem juntos, e as trocas funcionais entre o indivíduo e o meio exterior comportam dois aspectos interdependentes: 0 cognitivo e o afeito" (OLIVEIRA, 1989, p. s/n).

A visão de Oliveira et al. (1989) trata o corpo humano como responsável por situar o indivíduo no espaço por meio da cognição e conectar o ser às relações pessoais e coletivas, permitindo a ação e o exercício da liberdade e da criatividade, processo que origina a percepção de objetos e depois a criação de linguagens e sistemas de signos com o objetivo de comunicar e dar sentido ao espaço.

As ideias de Oliveira identificam o corpo humano como receptor e emissor de informação, capaz de moldar a percepção de mundo das pessoas. Oliveira (1999) aponta que para perceber, representar e construir uma imagem do mundo exterior, o ser humano precisa movimentar-se, deslocar-se pelo espaço e, para isso, é necessário coordenar e associar as imagens interiorizadas e reconstruir mentalmente as suas representações.

Assim, o nosso trajeto de pesquisa busca identificar como os pichadores percebem o espaço e identificam nele lugares desejáveis ou a serem evitados no processo da pichação e, consequentemente, compreender como certas realidades externas aos indivíduos podem afetá-los, gerando algum tipo de juízo de valor em relação aos lugares, formando, assim, representações de mundo pleno de significados.

\section{MATERIAIS E MÉTODOS}

Esta pesquisa parte do pressuposto de que a experiência promove o processo perceptivo e a formação de imagens mentais do mundo exterior, construídas a partir de como as coisas dispostas no espaço geográfico se apresentam às pessoas. Nesse sentido, busca-se como parte do método capturar características e qualidades dos objetos inseridos no espaço e sua probabilidade de evocar atração ou hesitação num dado observador.

Essa abordagem se apresenta bastante útil ao estudo da pichação, pois nota-se no visual de alguns locais da cidade uma quantidade elevada de inscrições enquanto outros, possuem poucas ou, nenhuma inscrição. Nesse sentido, por meio da quantidade de pichações expostas na paisagem urbana, percebe-se um processo de comunicação entre os lugares e os pichadores, e que pode ser atribuído as características físicas ou simbólicos próprias das áreas escolhidas para inserir ou não uma inscrição.

Do mesmo modo, entende-se que os pichadores deslocam-se pelo espaço à procura de suportes onde deixar suas marcas impressas na paisagem e, a partir de sua percepção, atribuem significados ao espaço urbano. Durante a busca por lugares específicos onde encaixar suas inscrições no espaço urbano, os pichadores criam seus próprios filtros, dando significados específicos às coisas, organizando as informações vindas do mundo dentro de suas mentes, unificando-as com significados que retornam ao mundo, na forma de conhecimento direto e imediato, criando, assim, representações plenas de significados.

Assim, o mapeamento apresentado foi produzido por meio de experiências individuais dos pichadores e leva em consideração os significados que esses agentes dão aos espaços. Propõe-se com este estudo a combinação entre a narrativa dos pichadores sobre os espaços da cidade coletadas por meio de entrevistas semiestruturadas com a rotulação de uma planta cartográfica do Hipercentro de Belo Horizonte (Figura 2), e também, a rotulação de dois pares de plantas de fachadas frontais de casas (uma planta de fachada contem pichações e outra a não) e prédios (uma planta de fachada de prédio contem pichações e a outra, não) conforme as Figuras 3 e 4.

A planta cartográfica do Hipercentro de Belo Horizonte foi confeccionada no formato de impressão A1, sendo apresentada a cada um dos entrevistados. A planta cartográfica contém o delineamento dos quarteirões, o parcelamento e o desenho das construções, com destaque para a estrutura de prédios e casas residenciais, comerciais, públicas e privadas, trazendo, ainda, o nome das ruas e praças que compõem o Hipercentro da cidade e dos bairros circunvizinhos (Figura 2). Sobre esta planta, os entrevistados foram convidados a rotular os trechos de vias e partes das fachadas das edificações entendidos como locais desejados para a prática da pichação ou a serem evitados.

$\begin{array}{llllll}\text { Caminhos de Geografia } & \text { Uberlândia - MG } & \text { v. 22, n. } 84 & \text { dez/2021 } & \text { p. 119-135 } & \text { Página } 122\end{array}$


Figura 2 - Belo Horizonte (MG): Planta Cartográfica do Hipercentro, 2018

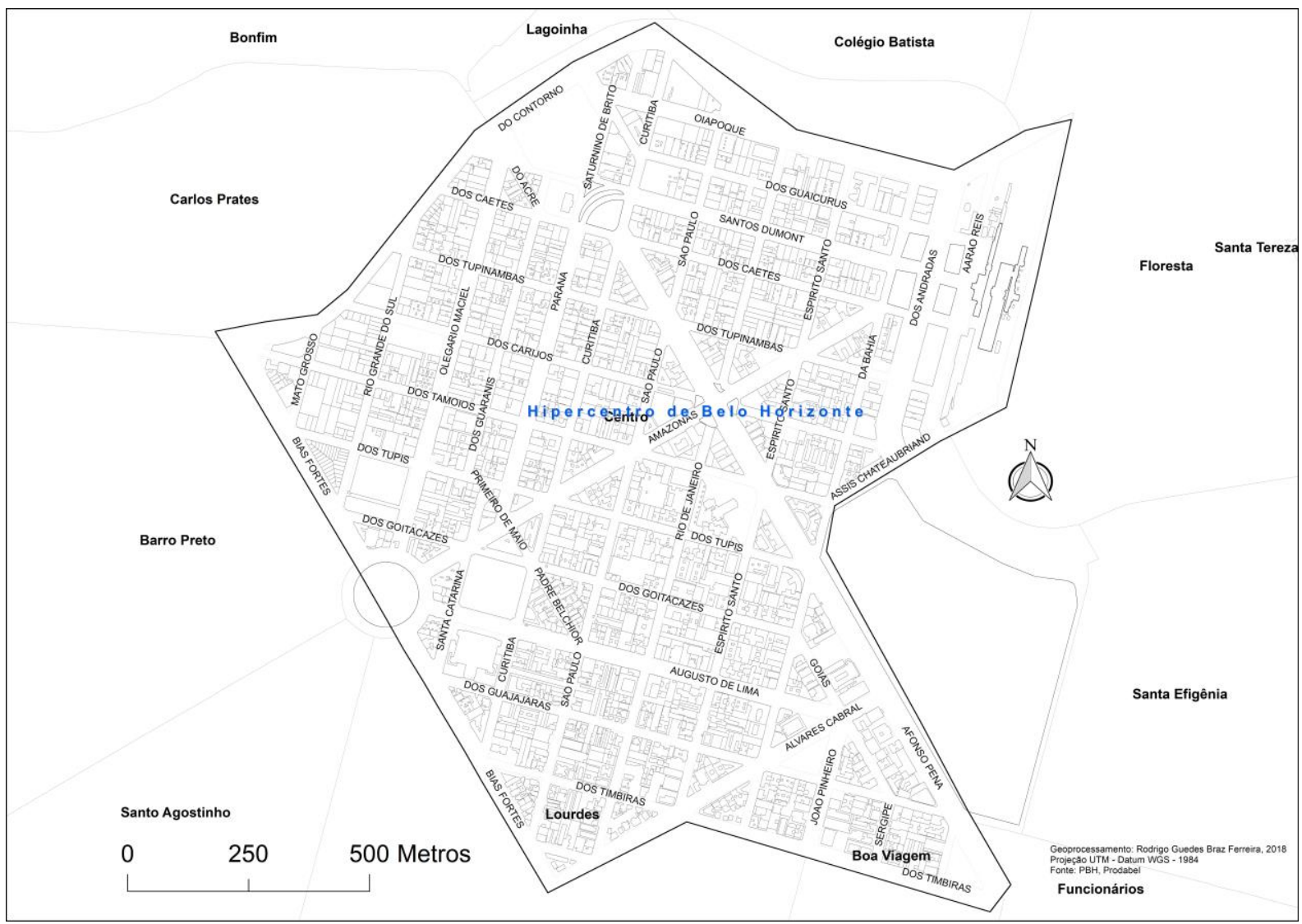

Fonte: Produzido pelo autor (2018)

Os pares de plantas de fachadas frontais de casas e prédios foram adaptados para o formato $\mathrm{A} 4$, tendo sido apresentados aos pichadores entrevistados. Cada par possui uma fachada frontal demarcada com pichações e outro isento de inscrições em sua superfície. Por meio da rotulação das plantas de fachadas frontais, à livre escolha dos pichadores, buscou-se explorar a seletividade espacial e os significados em uma escala espacial mais refinada, em busca da identificação dos espaços mais cobiçados para a prática da pichação no plano das edificações, conforme as Figuras 3 e 4.

Figura 3 - Belo Horizonte (MG): Planta de fachada Frontal de casa com e sem pichações, 2018
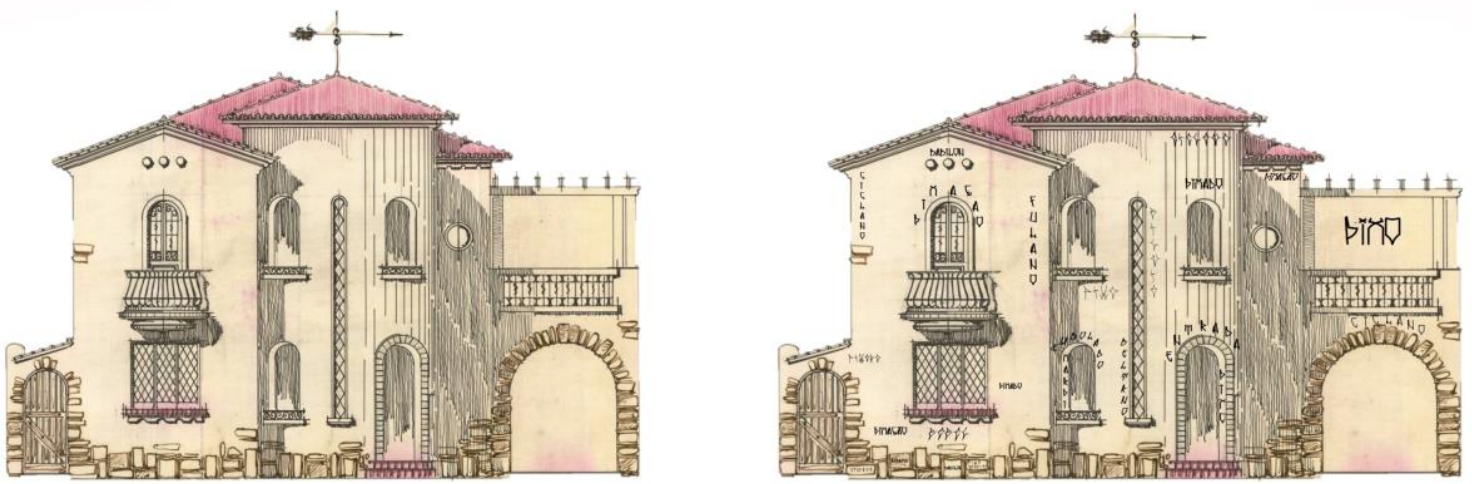

Fonte: NORONHA, 2001. Adaptado pelo autor (2018) 
Figura 4 - Belo Horizonte (MG): Planta de fachada Frontal de prédio com e sem pichações, 2018
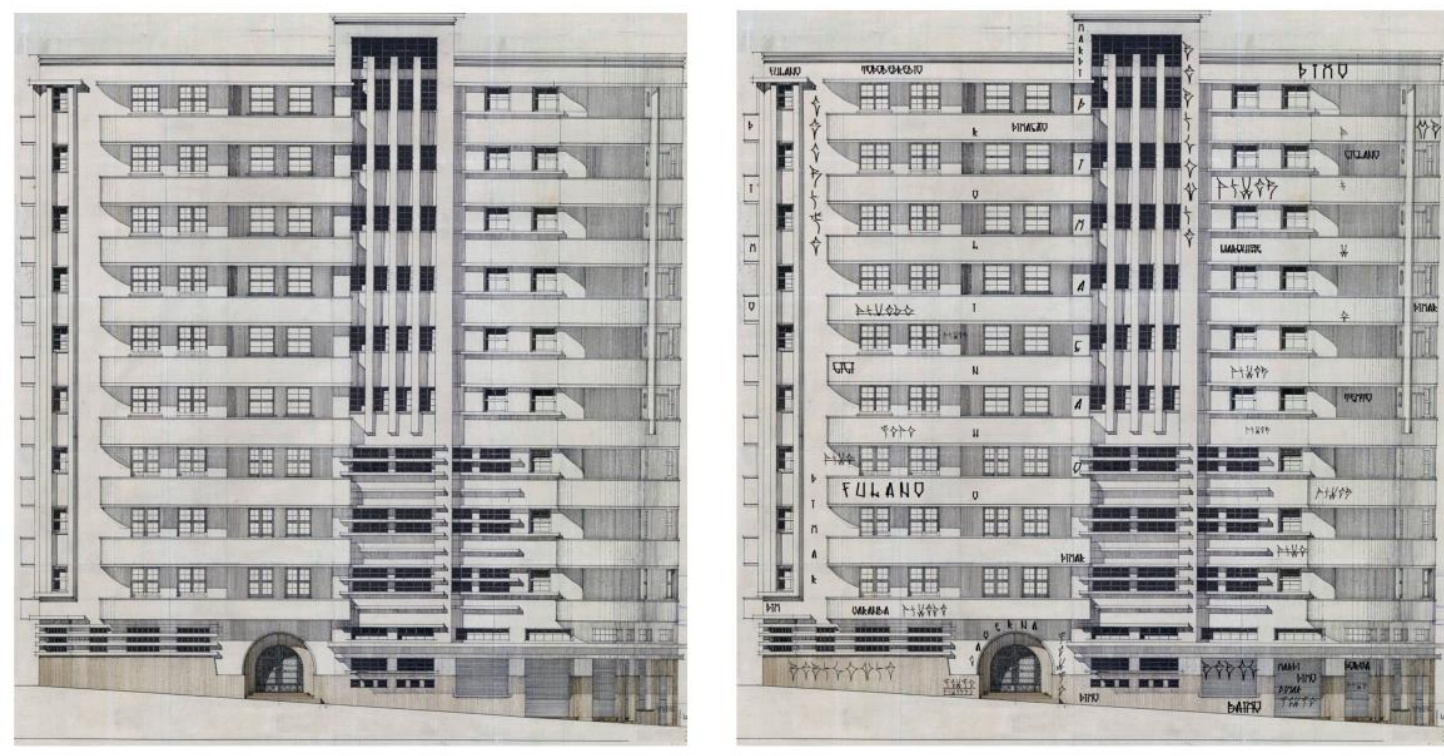

Fonte: NORONHA, 2001. Adaptado pelo autor (2018)

Por fim, os pichadores foram entrevistados com o auxílio de um roteiro com perguntas abertas, previamente definidas e adequadas ao universo da pichação e à sabedoria geográfica dos pichadores. As entrevistas foram gravadas, transcritas e analisadas na busca por padrões de discursos sobre os espaços percebidos pelos pichadores. O roteiro de entrevista foi aplicado imediatamente após a apresentação e rotulação da planta cartográfica e das plantas de fachada frontais.

A seleção da amostra de pichadores envolvidos neste trabalho se deu por meio da técnica bola de neve. Nesta estratégia as redes de relações dos entrevistados são exploradas, tendo os primeiros entrevistados indicado um conjunto de contatos, que, por sua vez, também foram indicando outros potenciais entrevistados, de modo que a finalização do processo de seleção e abordagem se deu com a saturação das redes sociais dos entrevistados.

Após a coleta de dados, realizou-se um apanhado geral dos padrões apresentados nos mapas e também do conteúdo extraído das imagens dos prédios e casas e das entrevistas. As plantas cartográficas foram retrabalhadas e superpostas em ambiente QGIS $3.2^{2}$, o que possibilitou compará-las de modo a identificar padrões e mapas sintéticos que evidenciam os locais mais valorizados ou evitados pelos entrevistados no Hipercentro da cidade. Assim como na organização das plantas cartográficas, as plantas das fachadas frontais também foram comparadas uma a uma, de modo a identificar e codificar padrões espaciais, gerando, posteriormente, imagens síntese que evidenciam os locais mais valorizados ou evitados pelos entrevistados em relação às fachadas de casas e prédios.

\section{O UNIVERSO DA PICHAÇÃO E A SUA SELETIVIDADE ESPACIAL}

Foram entrevistados seis pichadores, de faixa etária entre 21 e 32 anos, vindos de diferentes bairros populares de Belo Horizonte e Região Metropolitana. Os entrevistados possuem escolaridade acima do ensino médio, sendo que quatro deles trabalham, enquanto outros dois estudam. O tempo de experiência na pichação também é diverso e extenso, contando os mais experientes com 19 anos de prática e os menos experientes, com nove anos de pichação nas ruas. Apesar dessa diversidade, há elementos comuns entre os relatos dos pichadores entrevistados sobre a estrutura e a hierarquia interna nos grupos de pichadores, modo de organização e, também, a natureza contestatória da ação.

Segundo os entrevistados, a comunidade da pichação possui um sistema hierárquico estabelecido em bases morais, no qual os líderes dos grupos são geralmente escolhidos por sua sabedoria ao lidar com as situações de risco inerentes àquele universo e, ainda, por terem um conjunto de qualidades individuais

${ }^{2}$ QGIS versão 3.2 Bonn é um software livre utilizado para criar mapas, realizar análises espaciais e gerenciar dados (QGIS.org, 2018).

$\begin{array}{llllll}\text { Caminhos de Geografia } & \text { Uberlândia - MG } & \text { v. 22, n. } 84 & \text { dez/2021 } & \text { p. 119-135 } & \text { Página } 124\end{array}$ 
valorizadas pelos pichadores, quais sejam o rigor, audácia, resiliência e, principalmente, a disposição para pichar muito e/ou em lugares considerados estratégicos. Essas características são primordiais para a ascensão do indivíduo e dos grupos na comunidade de pichadores.

As entrevistas também destacaram pelo menos três tipos de organização na comunidade de pichadores. O primeiro se dá por meio da formação de grupos, cuja particularidade é o desenvolvimento de um alfabeto ou um nome original, que os destaquem e notabilizem na cena. O segundo se dá por meio de uma grife (uma marca) que representa a união de grupos de pichadores que se associam sob um mesmo símbolo, que é afixado juntamente com as marcas pessoais no ato da pichação. $O$ terceiro, está relacionado aos grupos que, antes de tudo, veem na pichação uma fonte de diversão e uma justificativa para explorar novos espaços da cidade, como um tipo de esporte de apelo urbano e de alto risco.

Contudo, as entrevistas revelaram que por traz da empreitada da pichação, existe o apelo ao registro da própria existência dos indivíduos por meio de uma inscrição que marque a paisagem da metrópole, mantendo-os em evidência - anônimos para os não iniciados e célebres entre os pichadores. Existe, ainda, um tipo de anti-discurso, ao considerado belo no visual da cidade, revelado na motivação de alguns pichadores, que por meio da sua ação protestam contra a propriedade privada e denunciam as injustiças do Estado e as múltiplas formas de exclusão social, mas, sem pertença ou apoio a partidos políticos ou similares. O ato de pichar, em si, é concebido como uma "agressão visual", uma resposta, direta a uma sociedade, violenta e excludente.

Os resultados também evidenciam que a seletividade espacial dos pichadores no Hipercentro está atrelada ao perigo inerente à pichação, à reminiscência e a busca pelo reconhecimento por eles almejado dentro da comunidade, que, por sua vez, é determinado pela quantidade de pichações e a ousadia associada aos locais pichados. O Hipercentro é uma importante plataforma para a antagonização dos pichadores em relação ao sistema. Um espaço cobiçado, que em função de sua visibilidade e simbolismo, transforma-se em canal de expressão de insatisfações pessoais. Um espaço de contestação e afronta às autoridades e à sociedade e seus valores conservadores, que se torna ainda mais atrativo tendo em vista os enormes riscos de autuação e as severas punições decorrentes. Afinal, pichar é a forma encontrada por esses indivíduos para se expressar na cidade e uma inscrição com frases de protesto, bem posicionada no centro da cidade, pode repercutir tanto entre os membros da comunidade de pichadores, como entre os demais integrantes da sociedade. Ao mesmo tempo, o Hipercentro possui a capacidade de evocar a competição e a cooperação entre os pichadores na disputa pelos espaços urbanos, na luta pelo título de pichador com o maior número de inscrições. Ao pichar no Hipercentro, galgam-se importantes degraus na hierarquia dos pichadores, sendo validados pela comunidade como pichadores da cidade e não apenas do bairro. No universo da pichação um envolvimento ativo e um olhar atento sobre certos espaços da cidade, incluindo o Hipercentro, pode proporcionar o alcance de um novo patamar na carreira do pichador.

A partir da rotulação dos instrumentos e das representações individuais geradas pelos pichadores entrevistados, é possível perceber por meio de mapas sintéticos a percepção dos espaços desejados e daqueles a serem evitados no Hipercentro de Belo Horizonte para a prática da pichação. Apesar de sutis diferenças entre os entrevistados, claros e consistentes padrões espaciais emergem.

Dentre os espaços cobiçados para a prática da pichação, destacam-se as fachadas frontais das edificações posicionadas ao longo de trechos dedas avenidas Amazonas, Santos Dumont, Paraná, Olegário Maciel, dos Andradas, Augusto de Lima; e das Ruas São Paulo, da Bahia, Aarão Reis; além dos prédios presentes nos quarteirões adjacentes à Praça Raul Soares (Figura 5). Segundos os entrevistados, essas vias possuem grande circulação de veículos de transporte público e privado, bem como de milhares de pessoas transitando a pé. Elementos que por si só as tornam áreas desejadas para o encaixe de inscrições.

Os pichadores entrevistados também indicaram trechos de vias com edificações cujas fachadas e muros possuem superfícies que absorvem e fixam a tinta, em especial a tinta spray, por mais tempo. São superfícies compostas de materiais como pedras de quartzitos e granitos não polidos e muros de concreto exposto. Foram também indicados pelos pichadores como locais desejados um conjunto de eixos viários marcados pela presença de fachadas ou muros pouco pichados, ou, ainda, propriedades percebidas como abandonadas e/ou descuidadas por seus proprietários, em situação de pouca manutenção. Os pichadores também assumiram o magnetismo que muros e fachadas recém pintados exercem sobre si. Segundo os entrevistados, após a remoção da tinta antiga e a aplicação de pintura nova, existe a possibilidade de assinarem um muro considerado "novo" e que não será pintado novamente por um longo tempo.

$\begin{array}{llllll}\text { Caminhos de Geografia } & \text { Uberlândia - MG } & \text { v. 22, n. } 84 & \text { dez/2021 } & \text { p. 119-135 Página } 125\end{array}$


Em contrapartida aos muros recém pintados, os pichadores indicaram na planta cartográfica áreas onde é possível encontrar fachadas ou muros onde estão presentes muitas pichações, encaixadas cuidadosamente em sua superfície, geralmente sem sobreposição. Tratam-se de fachadas denominadas pelos pichadores como "agendas", responsáveis pelo registro, desenvolvimento e conservação da memória coletiva da pichação. Graças às "agendas", é possível identificar os trabalhos de outros pichadores, antigos e atuantes, ou, aqueles que já não picham mais, seja por motivo de desistência ou fatalidade. Os pichadores iniciantes, também veem nas "agendas" a oportunidade de inserir as suas marcas junto àquelas dos indivíduos mais experientes e consagrados na cena. As "agendas" nem sempre estão localizadas nas partes mais visíveis dos eixos viários, tendo em vista a sua natureza conspícua.

Os entrevistados indicaram, ainda, trechos percebidos como de intensa movimentação de pessoas e comércio vibrante como áreas interessantes à prática da pichação, com destaque para as imediações de bares, terminais de ônibus e locais onde são realizados, em caráter regular ou esporádico, eventos culturais, como a Rua Aarão Reis nas proximidades do viaduto de Santa Tereza, conforme pode ser conferido na Figura 5. 
Figura 5 - Belo Horizonte (MG): Mapa de percepção de espaços rotulados como desejados no hipercentro de Belo Horizonte para a prática da pichação, síntese geral, 2019

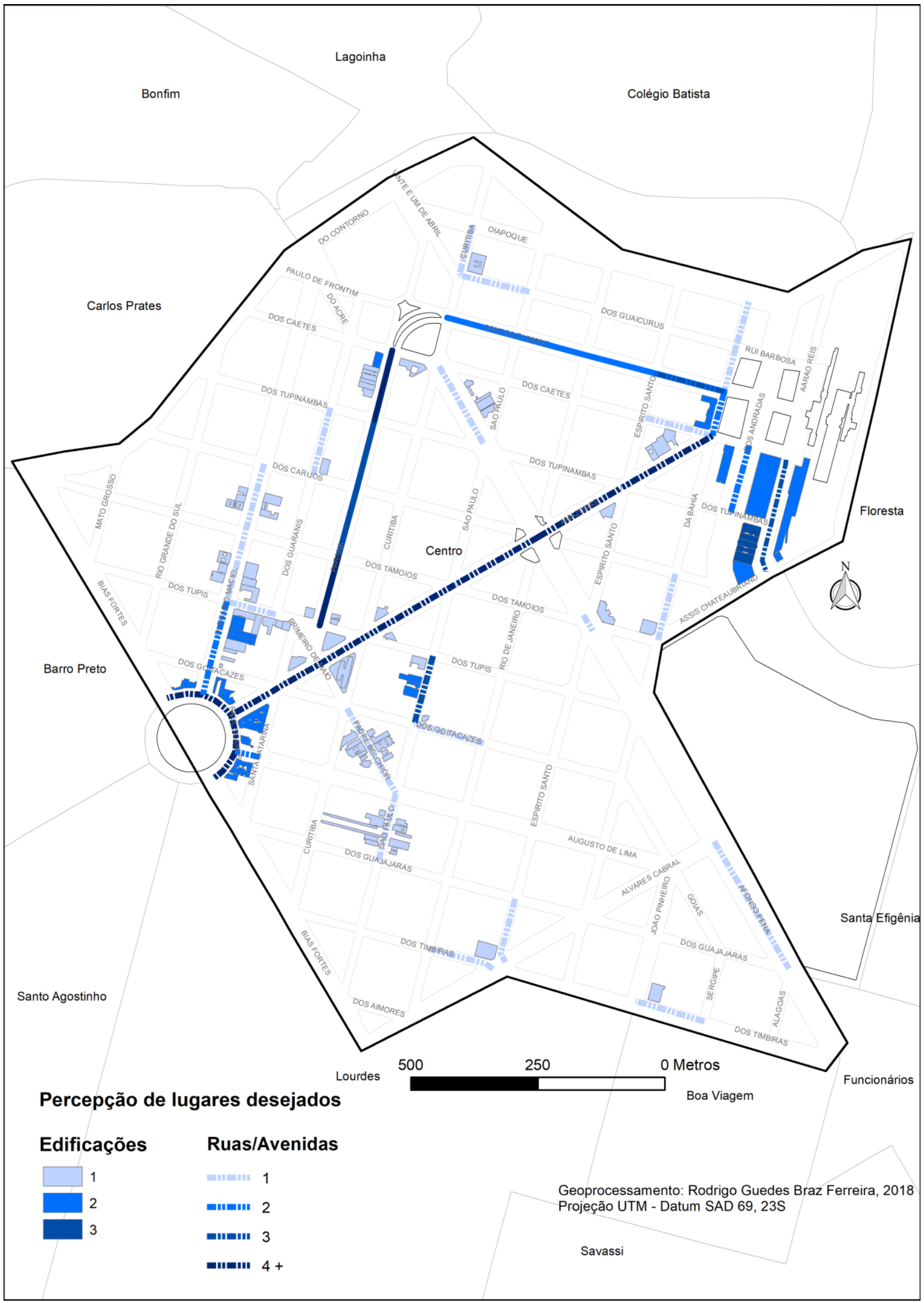

Fonte: Produzido pelo autor (2019) 
A Figura 6 traz a síntese da percepção dos espaços do Hipercentro de Belo Horizonte a serem evitados na prática da pichação. A referida figura indica que 23 vias foram rotuladas pelos pichadores, sendo que diferentemente da Figura 5, este mapa traz com maior destaque a indicação de equipamentos urbanos e edificações específicos, como praças, shopping, mercados, igreja e casa de eventos. Sobressaem dentre as indicações, a Rua São Paulo, nas imediações do Shopping Cidade; a Avenida do Contorno, na altura do batalhão da ROTAM 3 ; a Rua da Bahia, nas proximidades do batalhão da Polícia Militar; a Rodoviária; a Praça da Estação; trechos da Rua Guaicurus; e os equipamentos urbanos Mercado Central e Minas Centro.

Dentre os fatores dissuasores da pichação, segundo os entrevistados, figura a vigilância, seja ela formalmente instituída na presença ostensiva de agentes policiais e de segurança privada, seja informalmente estabelecido pelo intenso fluxo de pessoas. Para os entrevistados, certos lugares como o Mercado Central ou, ainda, a Praça Sete de Setembro são áreas frequentemente vigiadas por meio de guardas ou câmeras e, também, constantemente higienizados pelo poder público, o que desfavorece a permanência das pichações, representando um risco desnecessário e ineficiente. Por sua vez, lugares com grande fluxo de pedestres, embora sejam de interesse dos pichadores, exigem atenção redobrada, pois a vigilância se manifesta além daquela fornecida pela municipalidade sendo também realizada por transeuntes denunciadores, alcunhados pejorativamente pelos pichadores de "herói" (geralmente taxistas que rondam na madrugada), "zé povinho", "dedos de seta" ou, "x9" e, alertariam a sua ação às autoridades mais próximas aos locais.

Os entrevistados rotularam, ainda, como áreas indesejáveis para a prática da pichação os locais percebidos como perigosos em função da criminalidade ali presente. Neste sentido, foram rotulados a rodoviária e seu entorno, bem como a zona boêmia de Belo Horizonte, em especial os quarteirões onde se encontram os bordéis das Ruas Guaicurus e São Paulo. Para os pichadores entrevistados, essas áreas possuem uma territorialidade específica, marcada pela intensa movimentação dos seguranças particulares dos bordéis e de atividades vinculadas ao tráfico de drogas, conforme pode ser conferido na Figura 6.

\footnotetext{
${ }^{3}$ Batalhão de Rondas Táticas Metropolitanas, localizado na av. Do Contorno 777, Centro, Belo Horizonte

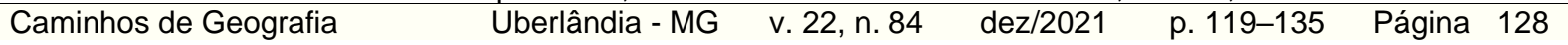


Figura 6 - Belo Horizonte (MG): Mapa de percepção de espaços rotulados como evitados no hipercentro de Belo Horizonte para a prática da pichação, síntese geral, 2019

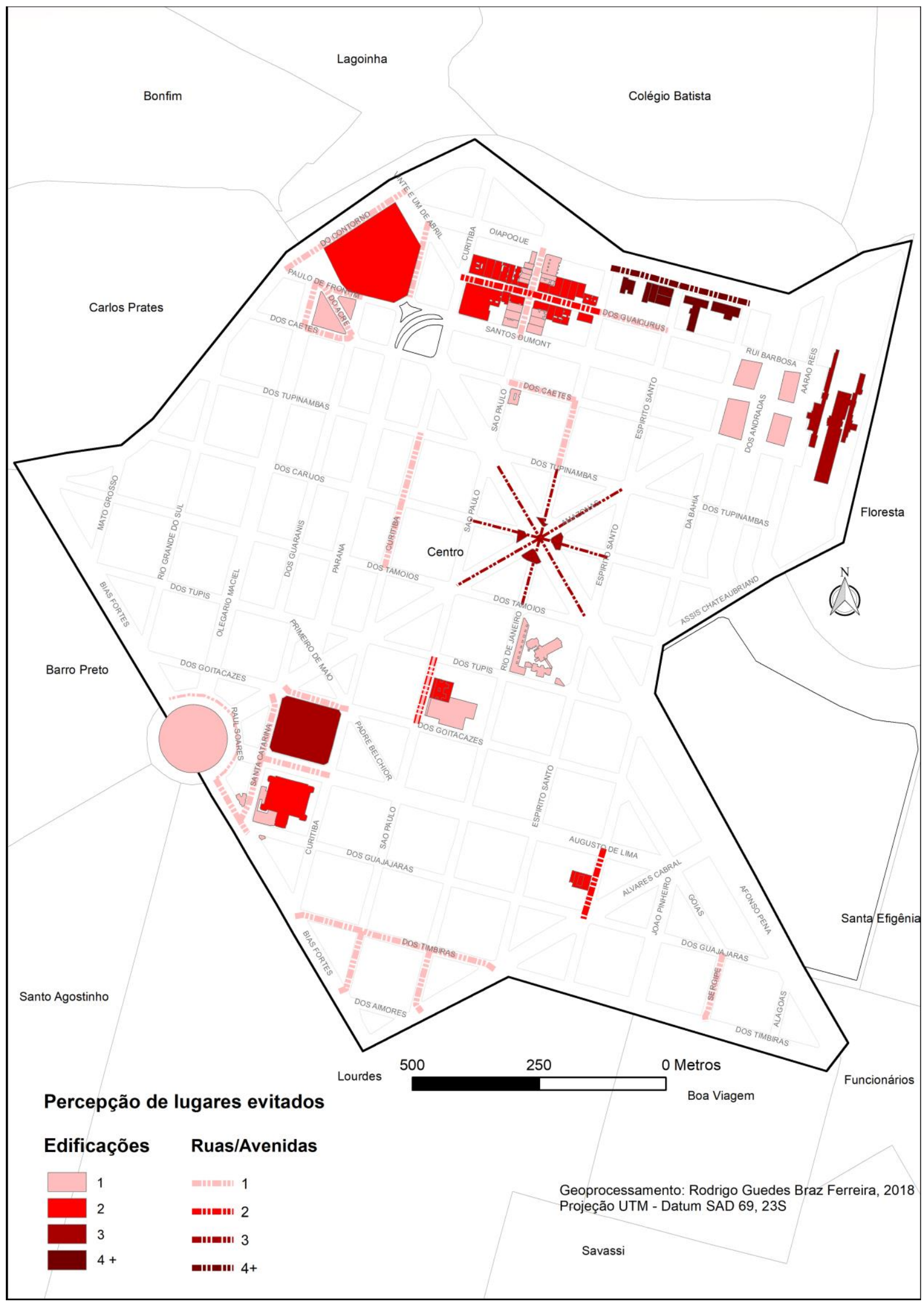

Fonte: Produzido pelo autor (2019) 


\section{ESPAÇOS COBIÇADOS E EVITADOS NAS FACHADAS PICHADAS E SEM PICHAÇÃO}

Trabalhando em uma escala mais refinada, os mapas-síntese das rotulações realizadas pelos entrevistados nas plantas de fachadas frontais revelam preferências e aversões relacionadas à prática da pichação. A (Figura 7) traz uma gradação em tons de azul indicativa de quantas vezes os recortes espaciais foram marcados pelos entrevistados como locais desejáveis para a pichação, sendo que a gradação em tons vermelhos indica quantas vezes os espaços foram marcados como lugares a serem evitados.

A partir das imagens e também dos relatos dos entrevistados foi possível perceber que os pichadores não selecionam aleatoriamente os espaços onde vão inserir as suas inscrições. Os lugares mais desejados para a pichação encontram-se, predominantemente, no nível do olhar, na parte superior da fachada, bem como na porção central da edificação, rotulando as fachadas de modo vertical e horizontal, buscando a maximização do uso dos espaços mais evidentes. Neste sentido, os entrevistados apontaram o interesse pelas áreas das edificações que permitissem uma visualização mais explícita das suas inscrições pelos pichadores concorrentes e pelos demais transeuntes.

Em contrapartida, as porções da fachada frontal rotuladas em vermelho revelam os espaços a serem evitados. O critério usado pelos pichadores envolve, principalmente, a escolha de espaços considerados pouco visíveis, principalmente a outros pichadores, ou ainda, a presença de superfícies que não fixam a tinta do spray. Assim, os pichadores marcaram as portas, janelas e também o rodapé da fachada, conforme revela a Figura 7.

Figura 7 - Belo Horizonte (MG): Planta de fachada frontal de casa sem inscrições em sua superfície, síntese de percepção dos espaços rotulados como desejados e evitados para se pichar, 2019
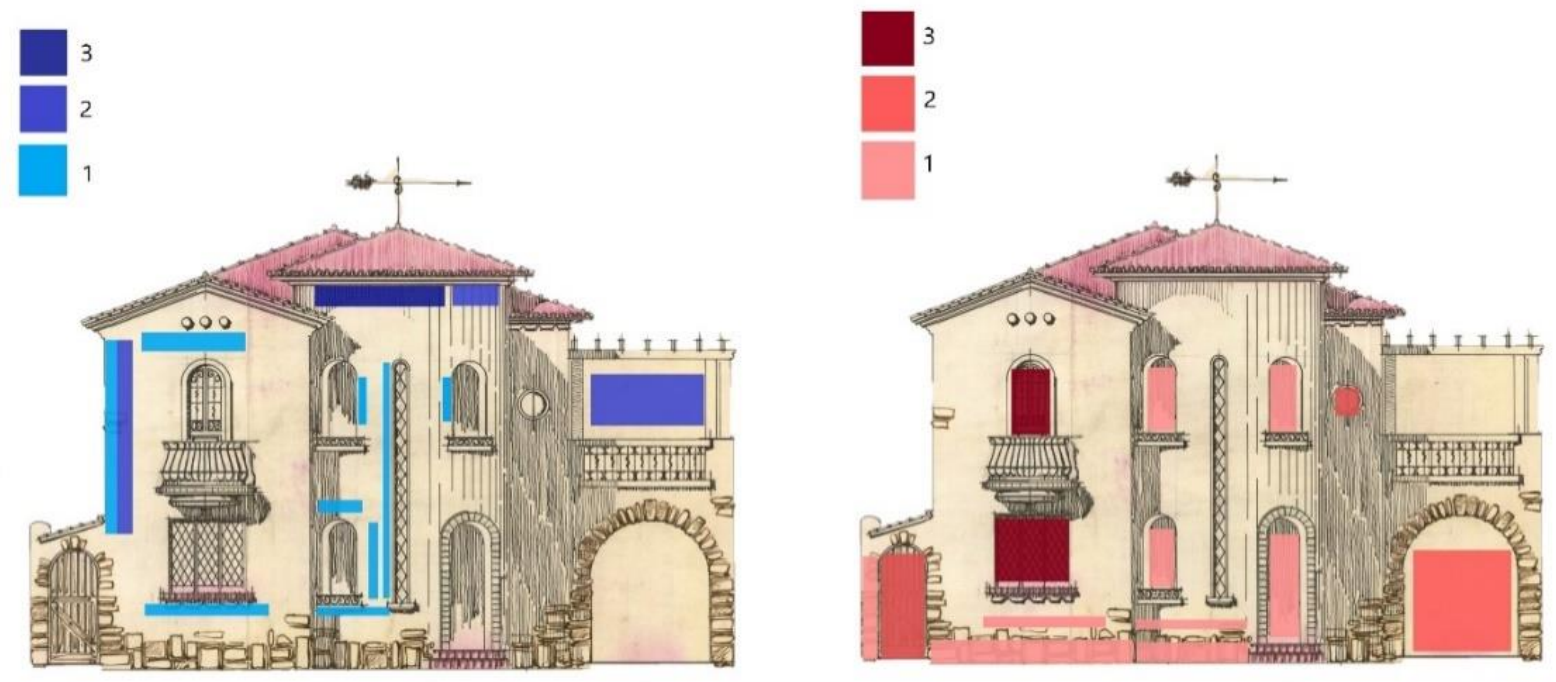

Fonte: NORONHA, 2001. Adaptado pelo autor (2019)

Assim como na figura anterior, os entrevistados ao serem apresentados às imagens de fachadas de casas já pichadas, rotularam como espaços desejáveis aqueles que garantiriam um posicionamento mais vantajoso para a visualização das suas marcas pessoais em relação àquelas preexistentes, evitando, no entanto, sobrepô-las. Os pichadores manifestaram a intenção de rotular os espaços entre os níveis médio e superior da fachada, adequando o formato do desenho das letras da pichação no sentido horizontal e vertical, na busca por um melhor posicionamento e o aproveitamento dos espaços remanescentes (Figura 8).

Como lugares a serem evitados nessas fachadas, os pichadores foram unânimes em apontar os locais considerados pouco visíveis, ou, ainda, com superfícies que dificultam a fixação da tinta spray, como, por exemplo, as portas, janelas e o rodapé da fachada. Os entrevistados também rejeitaram consonantemente a ideia de sobrepor a pichação de outro pichador. Porém, revelaram o desejo de marcar presença fazendo pichações bem próximas às pichações concorrentes, desafiando e intimidando-os sem, contudo, anular a pichação alheia, conforme a Figura 8.

$\begin{array}{llllll}\text { Caminhos de Geografia } & \text { Uberlândia - MG } & \text { v. 22, n. } 84 & \text { dez/2021 } & \text { p. 119-135 Página } 130\end{array}$


Figura 8 - Belo Horizonte (MG): Planta de fachada frontal de casa com inscrições em sua superfície, síntese de percepção dos espaços rotulados como desejados e evitados para se pichar, 2019
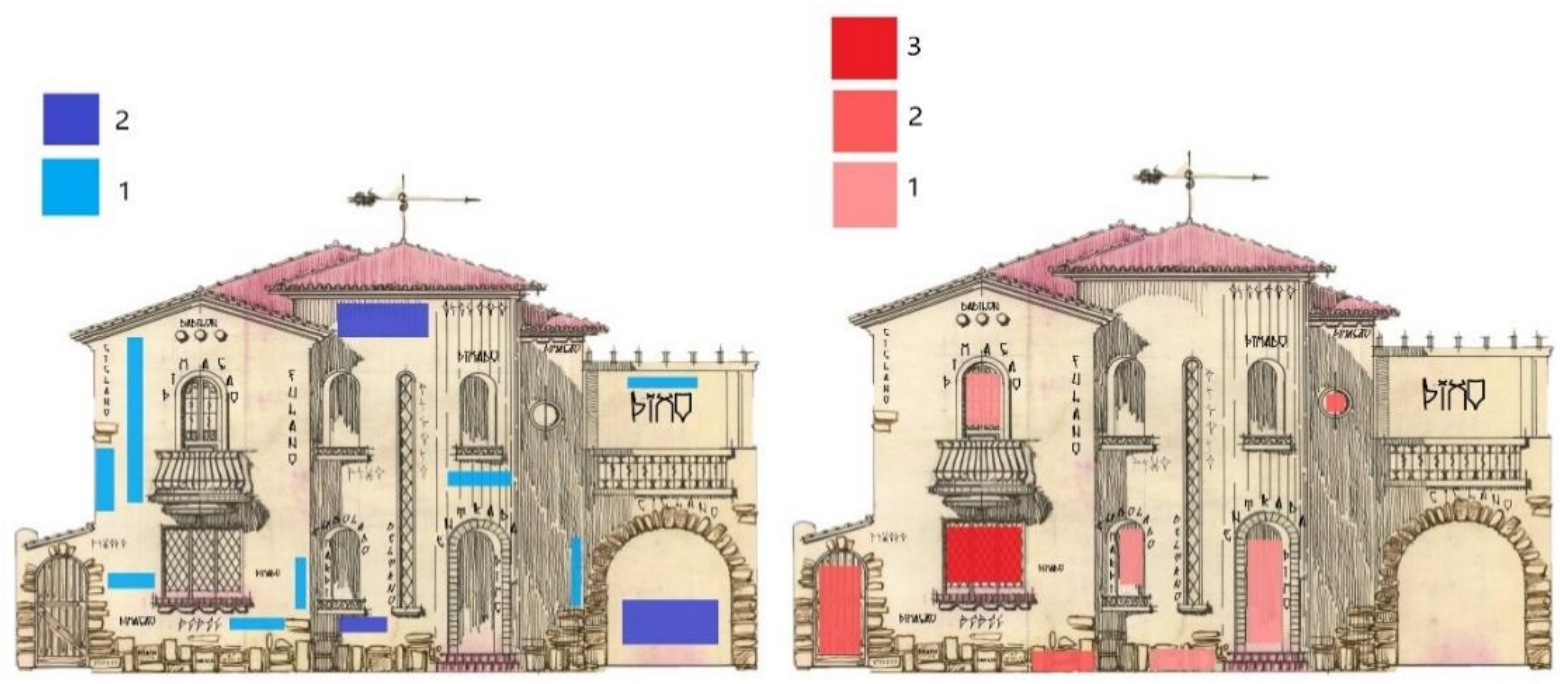

Fonte: NORONHA, 2001. Adaptado pelo autor (2019)

A imagem síntese dos espaços rotulados pelos pichadores como desejáveis em prédios sem pichações prévias revelou como principal critério de seleção a visibilidade dos locais na edificação, independentemente da altura, tendo havido indicações nos níveis inferior, médio e superior em relação ao olhar dos transeuntes. Em contraponto aos espaços considerados como desejáveis, os locais a serem evitados estariam relacionados às áreas da fachada entendidas como aquelas de baixa visualização, superfícies muito estreitas, que inviabilizam o desenho das letras, bem como aquelas que não favorecem a fixação de tintas spray, como portas de loja e janelas (Figura 9).

Figura 9 - Belo Horizonte (MG): Planta de fachada frontal de prédio sem inscrições em sua superfície, síntese de percepção dos espaços rotulados como desejados e evitados para se pichar, 2019
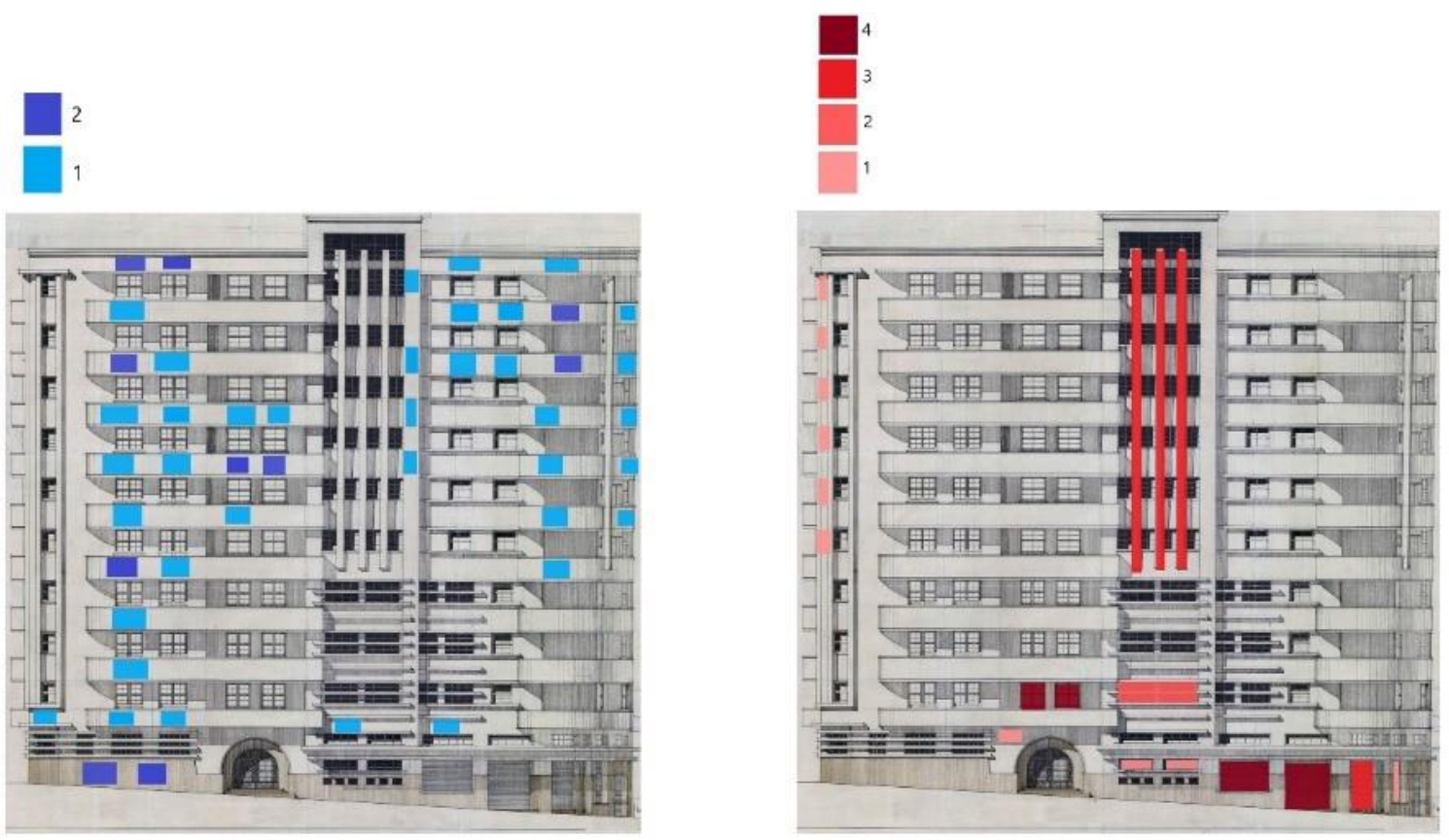

Fonte: NORONHA, 2001. Adaptado pelo autor (2019) 
Em relação às imagens síntese das fachadas de prédios com pichações prévias, notou-se que os pichadores foram consistentes, mantendo a predileção por lugares que favoreceriam a visualização das pichações (Figura 10). A diferença encontrada em relação à Figura 9 está no fato de ter aparecido no topo da edificação manifestações favoráveis à pichação, em claro antagonismo às marcas preexistentes. Dada a competição inerente à cena, pichar em local mais elevado do aquele demarcado por pichadores rivais é considerado ato de coragem e bravura, elevando o status do indivíduo na comunidade.

Em contraponto aos espaços considerados desejáveis, os espaços a serem evitados estão relacionados às áreas da fachada entendidas como de baixo poder de visualização, ou, ainda, superfícies que não fixam tintas ou lugares muito estreitos que inviabilizam o desenho das letras, como demonstrado anteriormente. Os entrevistados também rejeitaram a ideia de sobrepor a pichação de outro pichador, compreendendo o esforço e os riscos envolvidos na pichação da fachada de um prédio. Porém, guardando coerência com Figura 9, os entrevistados manifestaram o desejo de aplicar as suas pichações próximas àquelas preexistentes, de modo a marcar presença e intimidar a concorrência (Figura 10).

Figura 10 - Belo Horizonte (MG): Planta de fachada frontal de prédio com inscrições em sua superfície, síntese de percepção dos espaços rotulados como desejados e evitados para se pichar, 2019
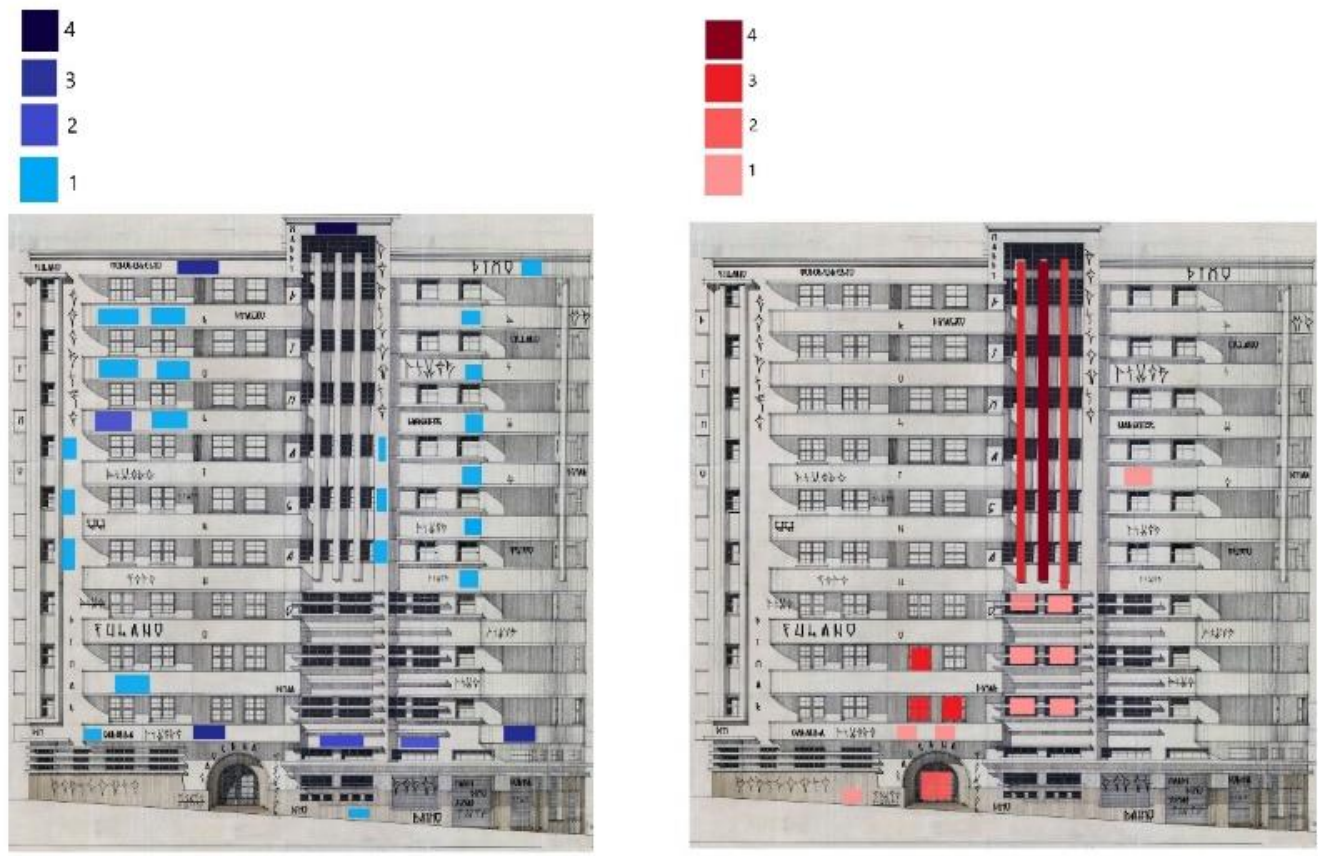

Fonte: NORONHA, 2001. Adaptado pelo autor (2019)

\section{CONSIDERAÇÕES FINAIS}

Este estudo de percepção e comportamento urbano trabalhou com base na perspectiva do indivíduo e buscou entender como os pichadores elegem os locais a serem pichados no Hipercentro, nos quarteirões e nas edificações. Assim sendo, a pesquisa trata de resultados comuns à percepção de todos os entrevistados.

O conceito de mundo-vivido originário da abordagem humanista e de caráter fenomenológico mostrou-se eficaz e, por meio dele, esta pesquisa pôde considerar as informações originadas da experiência dos pichadores entrevistados e assim colaborar com a revelação de como a cidade é interpretada e usada pelos pichadores.

Os resultados da pesquisa sugerem que a percepção espacial do pichador está associada à reminiscência e ao futuro, espaço/lugar almejado enquanto pichador na própria comunidade, o que é refletido diretamente na paisagem da cidade impregnada de inscrições. Os pichadores não se arriscam pela invisibilidade da inscrição, do contrário não se preocupariam com as características locacionais dos

$\begin{array}{llllll}\text { Caminhos de Geografia } & \text { Uberlândia - MG } & \text { v. 22, n. } 84 & \text { dez/2021 } & \text { p. 119-135 Página } 132\end{array}$


suportes onde expõem os seus trabalhos para o mundo. Os pichadores se interessam por locais que possibilitem a visibilidade das suas inscrições, daí o interesse por áreas com intenso trânsito de pessoas, pois a notoriedade e a ascensão na comunidade da pichação se dão de maneira quantitativa e qualitativa por meio de escolhas espaciais. Ou seja, quem não é visto não é lembrado.

Em meio à elevada quantidade de informações vindas da memória e da experiência dos pichadores enquanto exploradores urbanos, detectou-se uma convergência entre as percepções espaciais desses indivíduos em relação aos locais onde pichar e não pichar e seus significados. A pesquisa também revelou que a pichação quando realizada em bairros populares não tem o mesmo impacto do que aquela realizada no centro da cidade, local de maior visibilidade e onde as circunstâncias locais e a grande vigilância fazem com que a pichação seja mais difícil de ser realizada, exigindo dos atores maior ousadia e técnica. Assim, pichar no centro implica maior visibilidade para as inscrições e maior reconhecimento para o pichador. Este aspecto nos leva a refletir sobre como a noção de localização, o posicionamento das pichações em si, é determinante para a conquista de popularidade e respeito entre os pichadores. Extrapolando a comunidade de pichadores, a escolha do local onde a pichação será realizada também pode gerar significativo impacto simbólico nas sociedades locais, expondo as forças de segurança e à municipalidade ao ridículo. Nesse sentido a sabedoria espacial dos pichadores sobre os significados atribuídos aos lugares - capaz de identificar os locais de maior importância para o estado e para os interesses das elites - media as decisões espaciais no processo de pichação.

A rotulação das plantas frontais das fachadas de casas e prédios também revelou a concordância entre as percepções espaciais dos pichadores em diferentes aspectos. Um deles está relacionado ao posicionamento da pichação em relação a outras pichações. Por meio da leitura do muro é possível identificar rivalidades e antagonismos na comunidade, definindo quem está em disputa com quem. No entanto, por maior que seja a rivalidade, em hipótese alguma os pichadores cogitam a prática do "atropelamento", entendido como a sobreposição de pichações preexistentes com novas inscrições, um modo de alienação do outro. Consequentemente, detectou-se a prática do "quebra-quebras vertical" nos muros e fachadas da cidade, quando os indivíduos ao trabalhar em superfícies saturadas de pichações, buscam identificar locais ainda não grafados, montando um policromático mosaico coletivo.

Outro aspecto relevante do código de comportamento espacial dos pichadores está relacionado ao significado de inserções de novos pichos acima ou na vizinhança imediata de pichações preexistentes, entendidos na cena como uma provocação, uma afronta, um aviso do tipo "eu estou acima de você" ou "eu estou aqui na sua cola", estimulando a competição entre esses atores pela demarcação da cidade.

Nesta disputa vertical e na busca pelo reconhecimento da comunidade, figurar acima de outros pichadores na edificação, especialmente no topo de casa e prédios, em locais de difícil acesso, aumenta a reputação do pichador. Entre os pichadores, esta reputação é definida de modo proporcional à elevação de suas inscrições em muros, casa e edifícios; ao nível de ousadia e técnica envolvidos nas pichações; e no volume de inscrições aplicadas no espaço urbano.

Os resultados decorrentes deste estudo são importantes, pois por meio da abordagem humanista da Geografia pôde-se mesclar conteúdos relacionados ao espaço geográfico, colhidos a partir de relatos e impressões de um grupo de pichadores, com a elaboração de mapas e figuras síntese, com o auxílio de técnicas de geoprocessamento. Essa combinação potencializou o entendimento do fenômeno da pichação e das escolhas espaciais realizadas pelos pichadores, utilizando o Hipercentro de Belo Horizonte como referência. Em relação ao fenômeno da pichação, o presente artigo traz uma relevante contribuição por tratar de tema ainda pouco explorado pela Geografia, identificando práticas, significados e comportamentos espaciais subjacentes ao fenômeno, evidenciando o quanto os elementos presentes nas paisagens urbanas podem interferir na tomada de decisões de agentes que interagem entre si e que usam a cidade como suporte para o seu complexo sistema de comunicação.

\section{AGRADECIMENTOS}

Este artigo é resultado de uma dissertação de mestrado cujo método de pesquisa foi avaliado, registrado e aprovado pelo comitê de ética em pesquisa vinculado ao sistema plataforma Brasil, sob o parecer técnico de número 3.149.043. Os autores agradecem à CAPES, ao CNPq e ao Programa de Pós-Graduação em Geografia - Tratamento da Informação Espacial da PUC Minas pelo apoio na produção desta pesquisa e também, aos pichadores pela participação na pesquisa.

$\begin{array}{llllll}\text { Caminhos de Geografia } & \text { Uberlândia - MG } & \text { v. 22, n. } 84 & \text { dez/2021 } & \text { p. 119-135 } & \text { Página } 133\end{array}$




\section{REFERÊNCIAS}

AMORIM FILHO, O. B. Evolução do Pensamento Geográfico e a Fenomenologia. Sociedade \& Natureza, Uberlândia, 11 (21 e 22), jan/dez, 1999 (Número especial de edição comemorativa, publicada em 2000).

BELO HORIZONTE. Prefeitura de Belo Horizonte. Bases geográficas bairros de Belo Horizonte. Belo Horizonte, 2018. Disponível em: https://prefeitura.pbh.gov.br/estatisticas-e-

indicadores/downloads. Acesso em: 27 out. 2020.

BUTTIMER, A. Aprendendo o dinamismo do mundo vivido. In: CHRISTOFOLLETI, Antônio. Perspectivas da Geografia. São Paulo: Difel, (1982 [1976]).

CALDEIRA, T. P. R. Inscrição e circulação: novas visibilidades e configurações do espaço público em São Paulo. Novos estudos. - CEBRAP, São Paulo, n. 94, p. 31-67, nov. 2012.

CARVALHO, R. A. Entre prezas e rolês: pixadores e pixações de/em Belo Horizonte. 2013. 204 f. Dissertação (Mestrado em Antropologia Social) - Faculdade de Ciências Humanas, Universidade Federal de Minas Gerais, Belo Horizonte, 2013. Disponível em: http://hdl.handle.net/1843/BUBD-9ESH7U. Acesso em: 09 ago. 2020.

DINIZ, A. M. A.; FERREIRA, R. G. B.; ALCÂNTARA, S. A. Pichação, paisagem e território no Hipercentro de Belo Horizonte. Cadernos de Arquitetura e Urbanismo, v. 22, n. 30, p. 84- 103, 2015. Disponível em: https://doi.org/10.5752/P.2316-1752.2015v22n30p84 . Acesso em 12 ago. 2020.

DINIZ, A. M. A.; FERREIRA, R. G. B.; LACERDA, A. G. Territórios renitentes: os efeitos das políticas repressivas à pichação em Belo Horizonte (2011-2015). Caderno de Geografia, v. 27, n. 50, 2017. Disponível em: https://doi.org/10.5752/p.2318-2962.2017v27n50p589. Acesso em: 12 ago. 2020.

DINIZ, A. M. A.; FERREIRA, R. G. B.; LACERDA, A. G. Territórios Verticais: Grafismos Urbanos no Hipercentro de Belo Horizonte (MG). Caminhos da Geografia (UFU. Online), v. 20, p. 85-103, 2019. Disponível em: https://doi.org/10.14393/RCG207145174. Acesso em: 12 ago. 2020.

EDIE, J. "Introduction," in P. Thevanez, What is Phenomenology (Chicago: Quadrangle Books, 1962, trans. J. Edie).

ENTRIKIN, J. N. Contemporary Humanism in Geography. Annals of the American Geographers, v.66, n.4, p.615-632, 1976.

HOLZER, W. A geografia humanista: sua trajetória de 1950 a 1990. [livro eletrônico] Londrina: EDUEL, 2016.

HUSSERL, E. Meditações cartesianas: introdução à fenomenologia. Trad. F. Oliveira. São Paulo:

Madras, 2001, (Original publicado em 1931).

ISNARDIS, A. Pinturas rupestres urbanas: uma etnoarqueologia das pichações em Belo Horizonte. Revista de Arqueologia, v. 10, n. 1, p. 143-161, 30 dez. 1997. Disponível em https://doi.org/10.24885/sab.v10i1.124. Acesso em: 12 ago. 2020.

LODI, M. I. H. A escrita das ruas e o poder público no projeto Guernica de Belo Horizonte. 2003. 234 f. Dissertação (Mestrado em Sociologia) - Programa de Pós-Graduação em Ciências Sociais, Pontifícia Universidade Católica de Minas Gerais, Belo Horizonte, 2013. Disponível em:

http://www.biblioteca.pucminas.br/teses/CiencSociais_LodiMI_1.pdf. Acesso em 08 ago. 2020.

MARANDOLA JUNIOR, E. Arqueologia fenomenológica: em busca da experiência. Terra Livre, AGB, ano 21, v.2, n.25, p.67-79, 2005. Disponível em:

http://www.agb.org.br/publicacoes/index.php/terralivre/article/view/398/37. Acesso em: 02 ago. 2020.

MONDARDO, M. L.; GOETTERT, J. D. Territórios simbólicos e de resistência na cidade: grafias da pichação e do grafite. Revista Terr@ Plural, Ponta Grossa, v. 2, n.2, p. 293- 308, 2008.

MOREN, A. B. A Vida dos Muros Cariocas: o grafite e as apropriações do espaço público de 2007 a 2009. 2009. 137 f. Dissertação (Mestrado em Geografia) - Programa de Pós-graduação em Geografia, Universidade Federal do Rio de Janeiro, Rio de Janeiro, 2009. Disponível em: http://objdig.ufrj.br/16/teses/718807. pdf. Acesso em: 02 ago. 2020.

MOURA, T. S. R. PIXADORES, GRAFITEIROS E SUAS TERRITORIALIDADES: apropriações socioespaciais na cidade do Recife. 2014. 169 f. Dissertação (mestrado em Geografia) - Programa de Pós-graduação em Geografia, Universidade Federal de Pernambuco, Recife, 2014.

\begin{tabular}{llllll}
\hline Caminhos de Geografia & Uberlândia - MG & v. 22, n. 84 & dez/2021 & p. 119-135 & Página 134
\end{tabular}


NORONHA, C. 100 anos de Modernidade: Anuário da Arquitetura de Belo Horizonte: Fundação João Pinheiro, 2001.

OLIVEIRA, L.; MACHADO, L. "A Percepção da Paisagem como Metodologia de Investigação Geográfica". IV Impactos Geográficos. II Encuentro de Geógrafos de América Latina, Montevideo, Uruguay,1989. [s.n]. não paginado.

OLIVEIRA, L. Percepção e Representação do Espaço Geográfico. In: DELRIO, Vicente; OLIVEIRA, Lívia (orgs). Percepção Ambiental: a experiência brasileira. São Paulo: UFSCar, 1999.

OLIVEIRA, L. Ainda Sobre Percepção, Cognição e Representação em Geografia. In.: MENDONÇA, Francisco (org.); KOZEL, Salete (org.). Epistemologia da Geografia. Curitiba: Ed. da UFPR, 2009.

PEREIRA, A. B. De rolê pela cidade: os pixadores em São Paulo. 2005. Dissertação (Mestrado em Antropologia) - Faculdade de Filosofia, Letras e Ciências Humanas, Programa de Pós-Graduação em Antropologia Social, Universidade de São Paulo, São Paulo, 2005.

PEREIRA, A. B. As marcas da cidade: a dinâmica da pixação em São Paulo. Lua Nova, São Paulo, n.79, p.143-162, 2010 Disponível em: http://dx.doi.org/10.1590/S0102-64452010000100007. Acesso em 13 ago. 2020

PRODABEL. Empresa de Informática e Informação de Belo Horizonte, Gerência de cadastro técnico GCOT. Base cartográfica digital de Belo Horizonte. Belo Horizonte, Prodabel, 2013.

SANTOS, J. M. O. Subversão na paisagem: do canto do graffiti ao grito da pixação. 2015. 169 f. Dissertação (Mestrado em Geografia) - Centro de Ciências Humanas, Letras e Artes, Programa de PósGraduação e Pesquisa em Geografia, Universidade Federal do Rio Grande do Norte, Natal, 2015. Disponível em: https://repositorio.ufrn.br/ispui/handle/123456789/20450. Acesso em: 10 ago. 2020.

QGIS. Versão 3.2 Bonn. [S.I.: s.n.], 2018. Sistema de Informação Geográfica QGIS. Projeto Open Source Geospatial Foundation.

SILVA, E. F. Pixo: o lado oculto ao direito. 2016. 187 f. Dissertação (Mestrado em Antropologia) Faculdade de Filosofia e Ciências Humanas, Programa de Pós-Graduação em Antropologia, Universidade Federal de Minas Gerais, Belo Horizonte, 2016.

SOARES, F. C. Pixação em Belo Horizonte, Ponto Urbe [Online], 12 | 2013, posto online no dia 31 julho 2013, consultado o 27 outubro 2020. URL: http://journals.openedition.org/pontourbe/565; DOI: https://doi.org/10.4000/pontourbe.565

SOARES, F. B. F. Nóis pixa, você pinta, vamos ver quem tem mais tinta: direito à cidade e resistência nos espaços urbanos. 2016. 137 f. Dissertação (mestrado em Direito) - Faculdade de Direito, Programa de Pós-Graduação em Direito, Universidade Federal de Minas Gerais, Belo Horizonte, 2016. Disponivel em: http://hdl.handle.net/1843/BUOS-ASJH49. Acesso em: 09 ago. 2020.

TARTAGLIA, L. R. S. Geograf(it)ando: a territorialidade dos grafiteiros na cidade do Rio de Janeiro. 2010. 180 f. Dissertação (Mestrado em Geografia) - Programa de Pós-Graduação em Geografia, Universidade Federal Fluminense, Niterói, 2010. Disponível em: http://livros01.livrosgratis.com.br/cp145716.pdf. Acesso em: 07 ago. 2020.

Recebido em: 15/08/2020

Aceito para publicação em: 09/11/2020 